\title{
High mortality rate of shipping fever cases in cattle caused by bovine herpesvirus type 1 (BoHV-1)
}

\author{
Eda Baldan TOKER ${ }^{1, a}$, Kadir YEŞiLiLBAĞ ${ }^{1, b, \bowtie}$, Özer ATEŞ ${ }^{1, c}$, Berfin KADİROĞLU ${ }^{1, d}$, \\ Gizem AYTOĞU' ${ }^{1, e}$
}

\author{
${ }^{1}$ Bursa Uludağ University, Faculty of Veterinary Medicine, Department of Virology, Turkey \\ aORCID: 0000-0003-2468-3945; ' 'ORCID: 0000-0003-1793-6879; ' ${ }^{\mathrm{O} C R C I D: ~ 0000-0001-7676-9033 ; ~}$

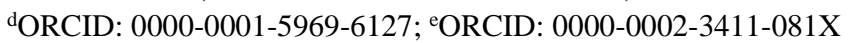 \\ $\triangle$ Corresponding author: kyesilbag@uludag.edu.tr \\ Received date: 02.12.2020 - Accepted date: 18.02.2021
}

\begin{abstract}
This study reports the high prevalence and molecular characterization of BoHV-1 infection in imported cattle with respiratory system disease after international transport. A high mortality rate of $14.16 \%$ (51/360) was reported in a group of animals imported from Hungary to Turkey in 2019. A total of 17 samples were evaluated (3 lung tissue and 14 nasal swab samples) from 15 cattle aged 6 to 9 months not vaccinated against BoHV-1. Virus isolation, polymerase chain reaction (PCR) and restriction endonuclease analysis (REA) procedures were performed within the scope of this study. By virus isolation in MDBK cells, cytopathologic effects was detected in 8 samples ( 3 lung tissue and 5 nasal swabs samples). The same eight samples were also found positive by BoHV-1 PCR targeting gC (UL44) gene region. According to the sequencing result, the sample (ID: 10054) dropped into a cluster of BoHV-1.1. The REA was applied to the samples to confirm the results of phylogenetic analysis. All of the isolates were identified in the subgroup BoHV-1.1 by REA. These results showed a high mortality risk for imported animals and the possibility for BoHV-1 entering the receiving country via imported animals after transport. This event is a serious problem both for the control of BoHV-1 as well as for animal health and welfare.
\end{abstract}

Keywords: Animal transport, BoHV-1, PCR, sequencing, shipping fever.

\section{Bovine herpesvirus tip 1'in (BoHV-1) neden olduğu yüksek ölüm oranlı nakil hastalığı vakaları}

Özet: Bu çalışmada, uluslararası nakil sonrası solunum sistemi hastalı̆̆ı tespit edilen ithal sığırlarda BoHV-1 enfeksiyonunun yüksek prevalansını ve etkenin moleküler karakterizasyonunun bildirilmesi amaçlanmıştır. 2019 yılında Macaristan'dan Türkiye'ye ithal edilen bir grup sığırda yüksek ölüm oranı (\%14,16; 51/360) tespit edildi. 6-9 ay yaş aralığında ve BoHV-1'e karş1 aşılanmamış 15 hayvandan sağlanan toplam 17 örnek (3 akciğer dokusu ve 14 burun svabı) değerlendirildi. Çalışma kapsamında virus izolasyonu, PCR ve restriksiyon endonükleaz analizi (REA) işlemleri uygulandı. MDBK hücrelerindeki virus izolasyonu çalışması sonucunda 8 örnekte (3 akciğer dokusu ve 5 burun svab1) sitopatolojik etki tespit edildi. BoHV-1'in gC (UL44) gen bölgesini hedefleyen PCR metodu aracılığıyla aynı 8 örnekte pozitif sonuç alındı. Nükleik asit dizi analizi için seçilen 1 izolatın (ID: 10054) filogeni analizinde BoHV-1.1 alt tipinde yer aldığı tespit edildi. Filogenetik analiz sonuçlarını doğrulamak için numunelere REA uygulandı ve tüm izolatların BoHV-1.1 alttipi içerisinde yer aldığı teyit edildi. Bu sonuçlar, nakliye sonrasında ithal hayvanlarda BoHV-1 kaynaklı yüksek mortalite oranının görülebileceğini ve uluslararası hayvan ticaretinde uygulanan tüm test protokollerine rağmen BoHV-1'in ithal hayvanlar aracılığıyla yeni bölgelere rahatlıkla taşınabileceğini göstermektedir. Bu durum hem BoHV-1'in kontrolü hem de hayvan sağlı̆̆ ve refahı için ciddi bir sorun teşkil etmektedir.

Anahtar sözcükler: BoHV-1, hayvan nakli, PCR, sekanslama, nakil hastalığı.

\section{Introduction}

Bovine herpesvirus-1 (BoHV-1), which causes infectious bovine rhinotracheitis (IBR) infection, leads to significant economic losses in the cattle industry. BoHV1 (renaming to bovine alphaherpesvirus-1) is a member of the genus Varicellovirus in the Alphaherpesvirinae subfamily, which belongs to the Herpesviridae family
(13). The viral genome with a length of around $135 \mathrm{~kb}$ contains about 70 proteins. Based on viral peptide models and genomic analysis, BoHV-1 comprises three subgroups namely BoHV-1.1, BoHV-1.2a, and BoHV-1.2b. While BoHV-1.1 is associated with respiratory and genital system infections, BoHV-1.2 has been mostly associated with genital system infections (19). BoHV-1.1 and BoHV- 
1.2 subtypes contain differences in glycoprotein $\mathrm{C}(\mathrm{gC})$ epitopes (25).

The virus can lead to fever $\left(40.5-42^{\circ} \mathrm{C}\right)$, anorexia, increase in respiratory rate, dyspnea, persistent severe cough, depression, and severe reduction in milk production in dairy cattle. IBR, the respiratory form of the infection can form subclinical, mild, or severe disease and have a very high morbidity rate (20). BoHV-1 settles in the sensory neurons of the trigeminal ganglion and germinal centers of the pharyngeal tonsils following acute infection and causes lifelong latency. Latent infection is reactivated under stressful conditions such as bad care, crowded pens, weaning, and transport (15, 27). Subsequently, the virus spreads and leads to transmission between housemates. Also, BoHV-1 accelerates apoptosis in $\mathrm{CD}^{+} \mathrm{T}$ cells and causes the immune system to be suppressed (15). Immune suppression by BoHV-1 can lead to the formation of pneumonia caused by secondary bacterial agents i.e. Mannheimia haemolytica, Pasteurella multocida, and Histophilus somni. IBR is not a lethal disease in general, but it can cause significant economic losses due to abortion, loss of weight and milk yield, die of newborn calves, infertility, insufficient feed conversion, secondary viral/bacterial pneumonia, and treatment costs. While the morbidity rate is approximately $30 \%$ due to IBR in dairy herds, losses ranging from $\$ 25$ to $\$ 55$ per cow can occur (29). Bovine respiratory disease (BRD) complex, also known as shipping fever, has been reported to cause at least 1 billion \$/year of economic loss for the US cattle industry (15). Not only latent infection and immunosuppression of BoHV-1 but also economic losses create an important problem for herd health. The presence of latent BoHV-1 infection causes the continuous circulation of the infection in the herd. For this reason, it is important that the quarantine applications before animal entry, screening of regularly herd for the presence of BoHV-1, and removing infected cattle from the herd. In the risk assessment study for biosecurity, it was reported that the high probability of transmission of BoHV-1, especially through animal transport by local movement or by introduction from another country (3).

Turkey had a cattle population of approximately 18 million and about 700,000 live cattle were imported only in 2019 (31). Although health control practices are applied in the origin countries, quarantine and screening test applications are important for diseases that may develop during and after transportation. However, if the animal is not acutely infected and the latent infection is not reactivated, negative results would be obtained in virological tests (33). The rules and test protocols to be applied during animal import to Turkey are determined by the Ministry of Agriculture and Forestry. For BoHV-1 controls in import cattle from European Union member states to the Republic of Turkey, different veterinary health control procedures such as allowing the import of either unvaccinated and sero-negative animals or animals vaccinated with EU approved killed marker vaccines and to be detected negative by IBR-gE ELISA, are implemented (23). However, there can be mistakes existed in the selected method or during the practices. This situation causes great problems for both the individual herds and national interest, especially in BoHV-1 infections that generally flow latently. Therefore, retesting or bringing the existing applications to a better level, imported animals for suspected diseases after transportation can contribute to both the importance of controlling BoHV-1 infections for international trade and the identification of the infection source. The aim of this study was to point out the risk of BoHV-1 infection for imported cattle showing signs of the respiratory system and high mortality rate after transport.

\section{Materials and Methods}

Case record of the herd: In the study, cattle imported to Southeastern Turkey (Adiyaman province) from Hungary were examined for the presence of BoHV-1. Imported cattle were 6 to 9 months old and no vaccine was applied before transport. All the imported animals were reported to be in a healthy appearance during the transport and kept under quarantine conditions in the same facility as a single import party. A total of 51 (14.16\%) from 360 imported animals were recorded to be died after transportation due to respiratory problems. Random sampling was performed in affected animals and sent to our laboratory for virological analysis. In addition, the isolation of Pasteurella multocida and Mannheimia haemolytica were recorded in these animals.

Field samples: A total of 17 samples (3 lung tissue and 14 nasal swab samples) obtained from 15 cattle (3 dead and 12 live cattle) were tested. The collected nasal swab samples were placed into tubes containing $2 \mathrm{~mL}$ sterile phosphate-buffered saline (PBS) and brought to the laboratory under a cold chain. Tissue samples were collected from the lungs of dead animals and they were delivered to the laboratory under the cold chain conditions. Approximately 1 gram of lung tissue material was homogenized in $9 \mathrm{~mL}$ sterile PBS. Both the swab samples and tissue homogenates were vortexed and centrifuged at $+4^{\circ} \mathrm{C}, 3000 \mathrm{rpm}$ for 20 minutes. The supernatants were collected into a stock tube by passing through a $220 \mathrm{~nm}$ filter and stocked at $-80^{\circ} \mathrm{C}$ until testing.

Cell culture and virus isolation: Madin Darby Bovine Kidney (MDBK) cell line (100,000 cells/mL) was used for virus isolation from samples and the production of test viruses. In the preparation of MDBK cell cultures, Dulbecco's Modified Eagle's Medium (DMEM) (Sigma, 
D7777, USA) supplemented with $10 \%$ fetal calf serum (FCS) (Capricorn, FBS-11A, South America), $100 \mathrm{UI} / \mathrm{mL}$ Penicillin/Streptomycin (BI, 03-031-1B, Israel) and 250 $\mu \mathrm{L} / \mathrm{mL}$ Amphotericin B solution (BI, 03-028-1B, Israel) were used. The cell line and FCS were free of bovine viral diarrhea virus and mycoplasma.

For virus isolation, 24-well plates coated with MDBK cells were used. All of the 17 samples were subjected to virus isolation. Two hundred microliters of inoculum were added onto MDBK and plates were incubated for $1 \mathrm{~h}$ at $37^{\circ} \mathrm{C}$ for virus adsorption. After incubation, $1 \mathrm{ml}$ of DMEM was added to the plate wells and the cells were examined under a microscope for 7 days for the presence of cytopathogenic effects (CPE). On the 7 th day, the cells were harvested by freezing at $-80{ }^{\circ} \mathrm{C}$ and thawing at $37^{\circ} \mathrm{C}$. All these steps were repeated with three blind passages.

Viral DNA extraction and PCR amplification: Viral DNA extracted from all the samples (supernatants of a nasal swab, lung homogenates, and cell culture supernatants) using the commercial nucleic acid isolation kit (Macherey-Nagel Nucleospin Virus, Germany). The collected DNA was subjected to PCR targeting the partial $\mathrm{gC}$ gene of BoHV-1. The primers PF: 5'CGGCCACGACGCTGACGA-3' and PR: 5'CGCCGCCGAGTACTACCCT-3' (11) were used in the reaction. The PCR master mix was performed in a volume of $50 \mu \mathrm{L}: 22 \mu \mathrm{L}$ DNase/RNase-free water, $25 \mu \mathrm{L}$ Maxima hot start Green Taq PCR master mix $(2 \times$, Thermo scientific, K1061), $1 \mu \mathrm{L}$ PF primer (50 pmol), $1 \mu \mathrm{L}$ PR primer $(50 \mathrm{pmol})$ and $1 \mu \mathrm{L}$ DNA. The thermal protocol profile was $95^{\circ} \mathrm{C}$ for $4 \mathrm{~min}$; 35 cycles of $95^{\circ} \mathrm{C}$ for $30 \mathrm{~s}$, $58^{\circ} \mathrm{C}$ for $30 \mathrm{~s}$ and $72^{\circ} \mathrm{C}$ for $35 \mathrm{~s}$, and a final extension at $72^{\circ} \mathrm{C}$ for $10 \mathrm{~min}$. The 575 -bp PCR product was detected by electrophoresis.

The samples obtained from the imported animals were also screened against common viruses of the respiratory system (BCoV, BVDV, BRSV, and BPIV-3) by RT PCR as described by Chou et al. for BCoV (9) and Toker et al. for BVDV, BRSV, and BPIV-3 viruses respectively (28).

Sequencing and phylogenetic analysis: One of the samples that were strongly positive in electrophoresis was selected. Sequence analysis was performed using Sanger dideoxy sequencing by a commercial company (Macrogen, South Korea). The $\mathrm{gC}$ gene sequences were aligned using the BioEdit program. Phylogenetic analysis was carried out by the Maximum likelihood method with 1000 bootstrap replication using MEGA-X. The reference sequences of the phylogenetic tree were obtained from GenBank.

Restriction endonuclease analysis (REA): For typing of the viral strains, a restriction endonuclease analysis was applied as described (17). Firstly, a multiplex
PCR was applied to the nucleic acids of all the field isolates via the RS1 primer pair, 493-bp (UL39, F: 5'TCGTCGAAGAGCGTCCACACA-3', and R: 5'ACCGCGCTGTACCGGCAGCT-3') and RS2 primer pair, 700-bp (US3, F: 5'-TACAAATCGGCGGCGCC AAA-3' and R: 5'-TTGTTGACGGCCAAGTATAA-3'). The RS1 and RS2 primers were replicated in UL39 open reading frame and US3 upstream intergenic region of BoHV-1, respectively, and have one HindIII restriction site (sequence AAGCTT). Briefly, the PCR reaction contained $1 \mu \mathrm{L}$ DNA, $1 \mu \mathrm{L}$ of both RS1 and RS2 sense and antisense primers (50 pmol), $25 \mu \mathrm{L}$ Maxima hot start Green Taq PCR master mix $(2 \times$, Thermo scientific, K1061), DMSO (6\%), and nuclease-free water up to 50 $\mu \mathrm{L}$. The thermal protocol profile was $95^{\circ} \mathrm{C}$ for $5 \mathrm{~min} ; 40$ cycles of $95^{\circ} \mathrm{C}$ for $30 \mathrm{~s}, 54^{\circ} \mathrm{C}$ for $1 \mathrm{~min}$ and $72^{\circ} \mathrm{C}$ for $1 \mathrm{~min}$, and a final extension at $72^{\circ} \mathrm{C}$ for $5 \mathrm{~min}$. Subsequently, the PCR products obtained were incubated with a fast digest HindIII enzyme (Thermo scientific, FD0504) at $37^{\circ} \mathrm{C}$ for 15 minutes. The REA products were visualized on the $1 \%$ agarose gel with Safe View Classic.

\section{Results}

Virus isolation and PCR: During the virus isolation, a total of 8 samples (3 lung tissue and 5 nasal swabs) produced CPE on MDBK cell monolayers on the different day of the incubation (Fig 1). By the applied PCR method according to partial $\mathrm{gC}$ gene region, the same 8 samples were found positive to produce a 575 bp product. In addition, since both lung tissue and nasal swab samples of two cattle were positive, BoHV-1 was found in 6 out of 15 cattle.

Besides, other common viruses of the respiratory system (BCoV, BVDV, BRSV, and BPIV-3) were also investigated in these cattle and found negative.

BoHV-1 sequencing and phylogenetic analysis: After sequencing of the isolate BoHV-1/10054, which was strongly positive in PCR, phylogenetic analysis was performed with previously reported $\mathrm{gC}$ gene sequences of the BoHV-1 genome. The isolate 10054 was in the cluster with BoHV-1.1 (Fig 2). The obtained sequence has been deposited to GenBank (Accession number: MW316648).

Restriction endonuclease analysis: For further confirmation of the phylogenetic classification of the isolate BoHV-1 10054, the REA was performed. The REA results were evaluated as for the criteria: (i) BoHV-1.1 subtype shows no cleavage both in RS1 and RS2 fragments; (ii) BoHV-1.2a subtype is not cleaved in the RS1 fragment, while the RS2 fragment is divided into 2 sub-fragments; (iii) BoHV-1.2b subtype was also cleaved into 2 sub-fragments, both in RS1 and RS2 fragments. According to this assay, all of the tested eight isolates dropped in the group of BoHV-1.1 (Fig 3). 


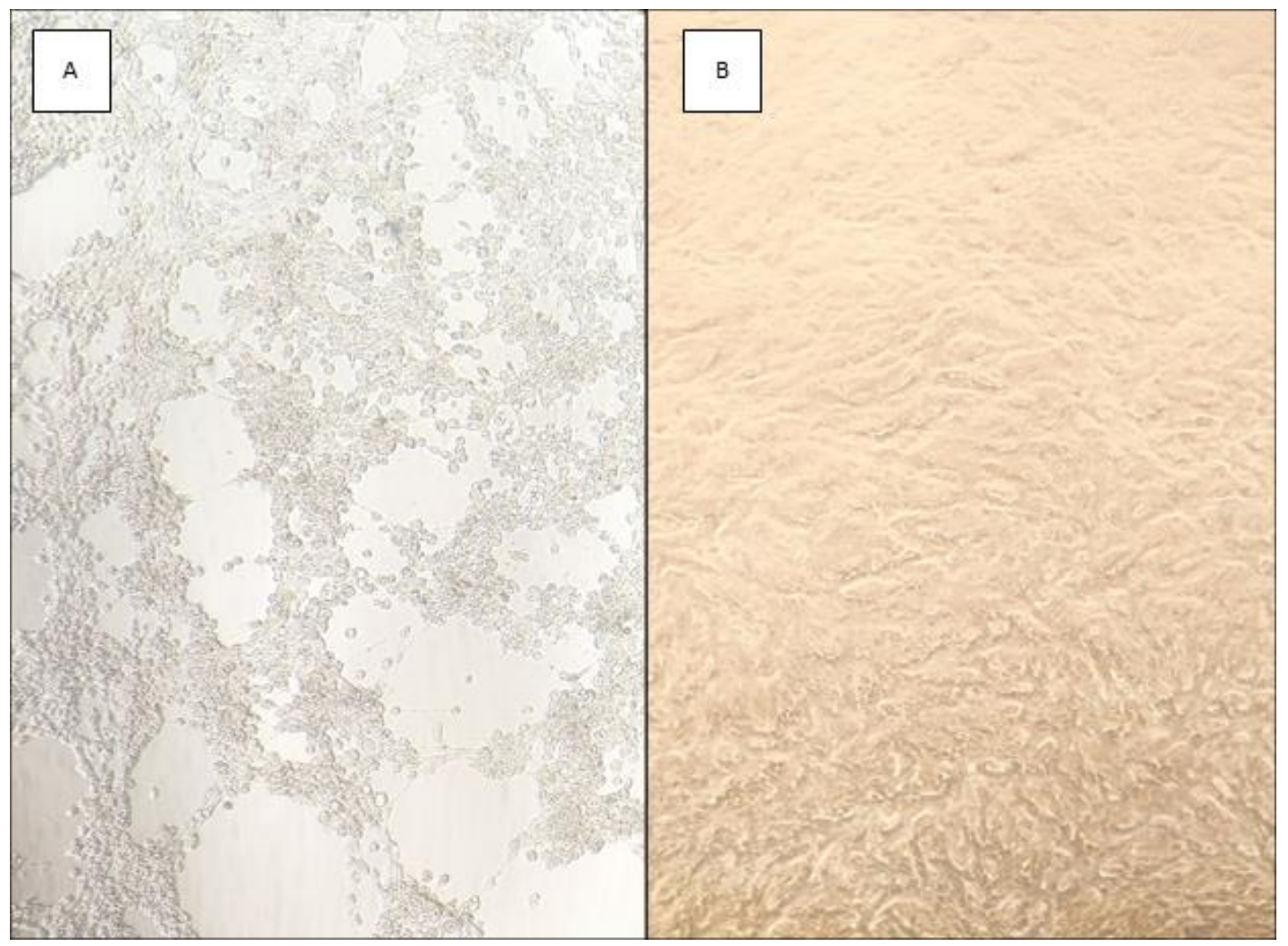

Figure 1. Microscope images were obtained in virus isolation (x20 magnification).

A: Cytopathologenic effect of nasal swab sample 10054 ( $1^{\text {st }}$ passage level) at $96 \mathrm{~h}$ p.i. B: Uninfected MDBK cell culture.

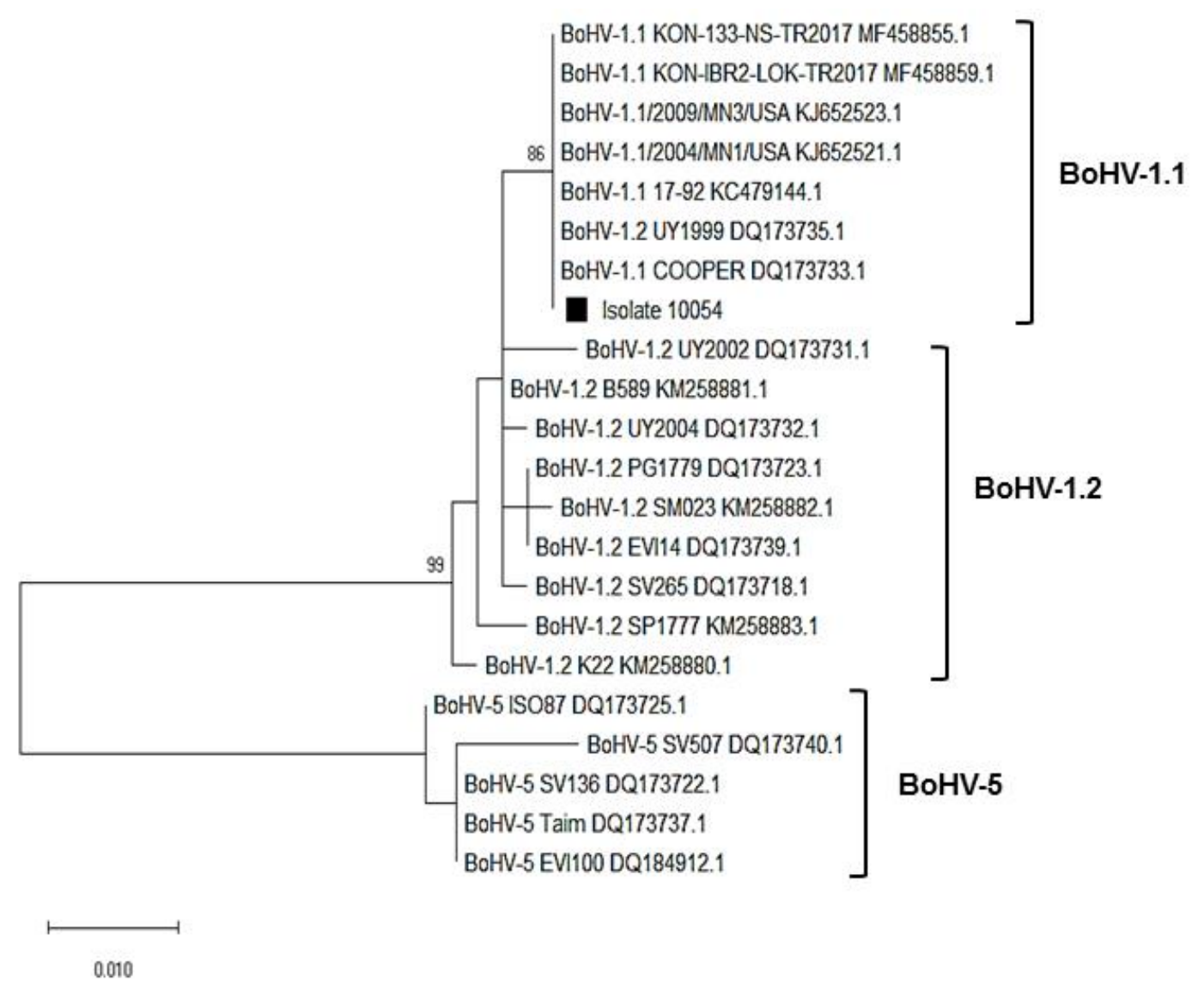

Figure 2. Phylogenetic typing of BoHV sequences based on partial gC (UL44) gene coding sequences. Field strain is marked with a square. 


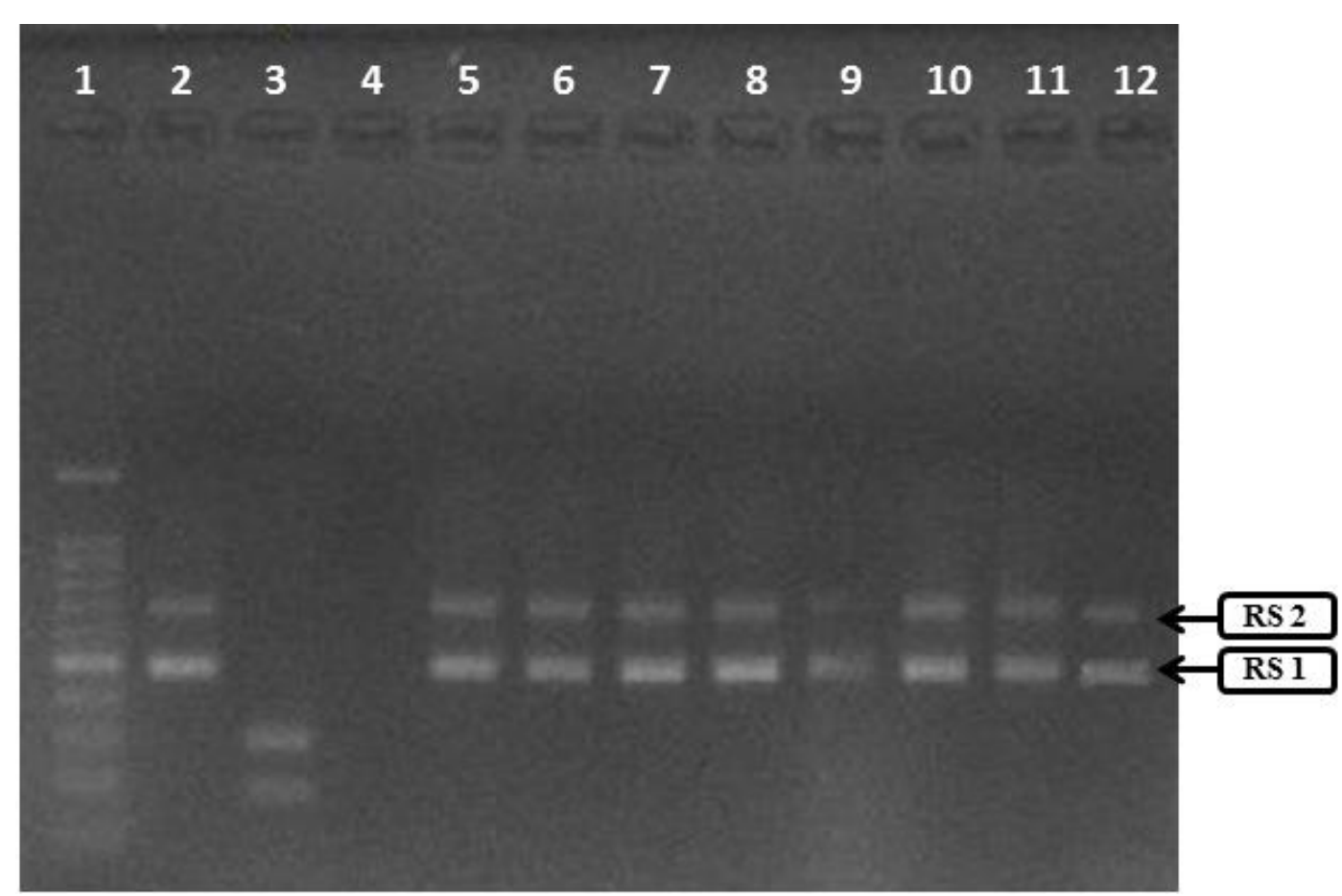

Figure 3. Restriction endonuclease analysis of BoHV-1 isolates.

Line (1): DNA ladder (100bp, GeneAll, GA-010, Korea); (2): BoHV-1 Cooper (BoHV-1.1); (3): BoHV-1.2b isolate (unpublished); (4): Negative control (ddw); (5-12): Samples 10047, 10048, 10049, 10051, 10054, 10059, 10060, 10061.

\section{Discussion and Conclusion}

After primary infection, BoHV-1 enters the sensory ganglia, becomes latent, and causes the animals to remain seropositive throughout their lifetime. Since the chance of detecting acute BoHV-1 infection is low, serological methods are used more often in the diagnosis of BoHV-1 (21). The agent BoHV-1 was detected for the first time in dairy cows in California, USA in 1953 (35), while it was isolated from cattle in Turkey in 1987 (6). The presence of BoHV-1 infection in Turkish cattle has been demonstrated by various studies $(4,22,30,36)$. Although BoHV-1 infection is common worldwide, there are differences in prevalence and incidence found in different territories. Despite the infection has been eradicated from some European countries including Austria, Denmark, Finland, Sweden, Switzerland, and Norway (1), it still exists in other countries including Belgium, Scotland, Ireland, Lithuania, and Hungary $(5,10,14,18,26)$.

In the present study, eight BoHV-1 isolates were obtained from severe respiratory cases of imported cattle after transport from Hungary to Turkey. We found that these 8 isolates were included in the BoHV-1.1 subtype using sequencing, phylogenetic analysis (Fig 2), and REA assay (Fig 3). These data indicate the compatibility between phylogenetic analysis and REA assay results as previously offered (17). In light of this result, BoHV-1 subtyping can be carried out more quickly and easily without the need for nucleic acid sequencing.
In addition to the virological results, Pasteurella multocida and Mannheimia haemolytica have been identified in the suspected cases (data not shown). Although mixed infections are frequently detected in the etiology of BRD; the primary cause of BRD is usually viral agents $(2,24)$. Since BHV-1 suppresses the immune system of the host by various mechanisms $(7,12,32)$, it can cause mixed infection and severe pneumonia especially with secondary bacterial infections (35). This situation leads to death in affected animals and serious economic problems for the enterprise.

The cattle that were tested in the study, were imported from Hungary to Turkey. This means approximately 2500 kilometers of road distance for imported cattle. Many previous studies have reported an increase in the level of corticosteroids in animals even after 4-6 hours of transport $(16,34)$. Significantly, another research has been reported that transportation stress increases serum concentrations of oxidative stress biomarkers that are related to episodes of BRD and mortality in calves (8). It has also been reported in previous studies that BoHV-1 is reactivated after transport (27) and has a high probability of transmission through animal transport (local movement or entry from other European countries) (3). In the present study, the detection of BoHV-1 in transported animals supports the formation of respiratory tract diseases (shipping fever) in animals after transport. The detected mortality rate of $14.16 \%$ 
(51/360) represents a very important economic impact of BoHV-1 induced shipping fever to beef cattle establishments.

In this study, BoHV-1 infection was detected in imported 6 to 9 months old animals possibly due to reactivation of the latency. Having clinical disease soon after arrival when the animals were in quarantine period also supports this hypothesis. The data of this study indicate that imported animals can still act as a source of BoHV-1 infection for cattle populations in the target country. This is particularly crucial for disease free regions and countries. When Turkey's high quantities of live animal import are considered, especially the entry of persistent or latent diseases can pose a serious problem for the country's economy. Official rules for animal importation described by the local authority should be strictly applied in the field. Any case, both the countries having IBR control program and individual enterprises in the countries with no official control program should be aware of BoHV-1 transmission risk by animal transport despite official protocols applied. Importantly, it is indisputable that those of infected animals will be the BoHV-1 reservoir throughout their lives.

\section{Acknowledgements}

Dr. EB Toker is granted for postdoc position by TUBITTAK Project No: 119 O 571.

\section{Financial Support}

This study was financially supported by Bursa Uludag University Research Fund, Project No: OUAP(V)2020/7.

\section{Ethical Statement}

All of the samples were sent to the laboratory by field veterinarians by sampling according to officials' ethical rules for animal welfare.

\section{Conflict of Interest}

The authors declared that there is no conflict of interest.

\section{References}

1. Ackermann M, Engels M (2006): Pro and contra IBReradication. Vet Microbiol, 113, 293-302.

2. Autio T, Pohjanvirta T, Holopainen R, et al (2007): Etiology of respiratory disease in non-vaccinated, nonmedicated calves in rearing herds. Vet Microbiol, 119, 256-265.

3. Benavides B, Casal J, Diéguez JF, et al (2020): Development of a quantitative risk assessment of bovine viral diarrhea virus and bovine herpesvirus-1 introduction in dairy cattle herds to improve biosecurity. J Dairy Sci, 103, 6454-6472.
4. Bilge-Dagalp S, Farzani TA, Dogan F, et al (2020): Molecular and antigenic characterization of bovine herpesvirus type 1 (BoHV-1) strains from cattle with diverse clinical cases in Turkey. Trop Anim Health Prod, 52, 555564.

5. Boelaert F, Biront P, Soumare B, et al (2020): Prevalence of bovine herpesvirus-1 in the Belgian cattle population. Prev Vet Med, 45, 285-295.

6. Burgu I, Akca Y (1987): First isolation of IBR virus in Turkey. Trop Anim Health Prod, 19, 56.

7. Carter JJ, Weinberg AD, Pollard A, et al (1989): Inhibition of T-lymphocyte mitogenic responses and effects on cell functions by bovine herpesvirus 1. J Virol, 63, 15251530.

8. Chirase NK, Greene LW, Purdy CW, et al (2004): Effect of transport stress on respiratory disease, serum antioxidant status, and serum concentrations of lipid peroxidation biomarkers in beef cattle American. J Vet Res, 65, 860-864.

9. Cho KO, Hasoksuz M, Nielsen PR, et al (2001): Crossprotection studies between respiratory and calf diarrhea and winter dysentery coronavirus strains in calves and RTPCR and nested PCR for their detection. Arch Virol, 146, 2401-2419.

10. Cowley RE, Holland PL (2011): $C-H$ activation by a terminal imidoiron (III) complex to form a cyclopentadienyliron (II) product. Inorganica Chim Acta, 369, 40-44.

11. Esteves P, Dellagostin O, Pinto L, et al (2008): Phylogenetic comparison of the carboxy-terminal region of glycoprotein $C(g C)$ of bovine herpesviruses (BoHV) 1.1, 1.2 and 5 from South America (SA). Virus Res, 131, 16-22.

12. Hinkley S, Hill AB, Srikumaran S (1998): Bovine herpesvirus-1 infection affects the peptide transport activity in bovine cells. Virus Res, 53, 91-96.

13. International Committee on Taxonomy of Viruses (2019): Virus Taxonomy: 2019 Release. Available at https://talk.ictvonline.org/taxonomy/ (Accessed January 20, 2021).

14. Jacevičius E, Šalomskas A, Milius J, et al (2008): Prevalence and control measures of infectious bovine rhinotracheitis in Lithuania. Anim Heal, 1, 49-53.

15. Jones C, Chowdhury S (2010): Bovine herpesvirus type 1 (BHV-1) is an important cofactor in the bovine respiratory disease complex. Vet Clin North Am-Food Anim Pract, 26, 303-321.

16. Kent JE, Ewbank R (1983): The effect of road transportation on the blood constituents and behaviour of calves. I. six months old. Br Vet J, 139, 228-235.

17. Maidana SS, Miño S, Apostolo RM, et al (2020): A new molecular method for the rapid subtyping of bovine herpesvirus 1 field isolates. J Vet Diagnostic Investig, 32, 112-117.

18. Msolla PM, Wiseman A, Selman IE (1981): The prevalence of serum neutralizing antibodies to infectious bovine rhinotracheitis virus in Scotland. J Hyg, 86, 209215.

19. Muylkens B, Thiry J, Kirten P, et al (2007): Bovine herpesvirus 1 infection and infectious bovine rhinotracheitis. Vet Res, 38, 181-209. 
20. Nandi S, Kumar M, Manohar M, et al (2009): Bovine herpes virus infections in cattle. Anim Heal Res Rev, 10, 86-98.

21. OIE (2017): Infectious bovine rhinotracheitis/ Infectious pustular vulvovaginitis, 1-19. In: OIE Terrestrial Manual.

22. Öner EB, Yeşilbağ K (2018): Seroprevalance of respiratory viruses and detection of persistent $B V D$ virus infection in beef cattle (in Turkish). Ankara Univ Vet Fak Derg, 65, 1-7.

23. Rebuplic of Turkey Ministry of Agriculture and Forestry (2020): Hayvan ve Hayvan Maddeleri Sağlik Sertifikaları (İthalat). Available at https://www.tarimorman. gov.tr/Konular/Veteriner-Hizmetleri/Ihracat-Ithalat/ Ithalat? Ziyaretci=Ihracat-Ithalat._(Accessed January 20, 2021).

24. Rice JA, Carrasco-Medina L, Hodgins DC, et al (2008): Mannheimia haemolytica and bovine resiratory disease. Anim Heal Res Rev, 8, 117-128.

25. Rijsewijk FAM, Kaashoek MJ, Langeveld, JPM, et al (1999): Epitopes on glycoprotein C of bovine herpesvirus-1 $(B H V-1)$ that allow differentiation between $B H V-1.1$ and BHV-1.2 strains. J Gen Virol, 80, 1477-1483.

26. Tekes L, Markos B, Kecskeméti S, et al (1999): Prevalence of bovine herpesvirus 1 (BHV-1) infection in Hungarian cattle herds. Acta Vet Hung, 47, 303-309.

27. Thiry E, Saliki J, Bublot M, et al (1987): Reactivation of infectious bovine rhinotracheitis virus by transport. Comp Immunol Microbiol Infect Dis, 10, 59-63.

28. Toker EB, Yeşilbağ K (2021): Molecular characterization and comparison of diagnostic methods for bovine respiratory viruses (BPIV-3, BRSV, BVDV, and BoHV-1) in field samples in northwestern Turkey. Trop Anim Health Prod, 53, 1-11.

29. Townley M (1971). Economic loss from an acute IBR outbreak in a dairy herd. Mod Vet Pract, 52, 72-73.

30. Tuncer-Göktuna P, Alpay G, Öner EB, et al (2016): The role of herpesviruses (BoHV-1 and BoHV-4) and pestiviruses $(B V D V$ and $B D V)$ in ruminant abortion cases in western Turkey. Trop Anim Health Prod, 48, 1-6.

31. Turkish Statistical Institute (2019): Dış Ticaret İstatistikleri Ara Mal1 İthalat1. Available at https://www.tuik.gov.tr/. (Accessed August 20, 2020).

32. Winkler MTC, Doster A, Jones C (1999): Bovine herpesvirus 1 can infect CD4+t lymphocytes and induce programmed cell death during acute infection of cattle. $\mathrm{J}$ Virol, 73, 8657-8668.

33. Winkler MTC, Doster A, Jones C (2000): Persistence and reactivation of bovine herpesvirus 1 in the tonsils of latently infected calves. J Virol, 74, 5337-5346.

34. Yagi Y, Shiono H, Chikayama Y, et al (2004): Transport stress increases somatic cell counts in milk, and enhances the migration capacity of peripheral blood neutrophils of dairy cows. J Vet Med Sci, 66, 381-387.

35. Yates WDG (1982): A review of infectious bovine rhinotracheitis, shipping fever pneumonia and viralbacterial synergism in respiratory disease of cattle. Can $\mathrm{J}$ Comp Med, 46, 225-263.

36. Yeşilbă̆ K, Güngör B (2008): Seroprevalence of bovine respiratory viruses in North-Western Turkey. Trop Anim Health Prod, 40, 55-60. 